\title{
Article ASSESSING THE IMPACTS OF URBINIZATION ON THE CLIMATE OF KUMASI
}

\author{
Caleb Mensah ${ }^{1 \ddagger} \mathbb{0}$, Julia Atayi ${ }^{2}$, Amos Kabo- bah $^{3}$, Marian Švik ${ }^{1}$ and Daniel Acheampong ${ }^{2}$ \\ 1 Global Change Research Institute, Bělidla 986/4a, 603 00, Brno, Czech Republic; calnumic@gmail.com \\ 1 Department of Civil Engineering, Kwame Nkrumah University of Science and Technology, Kumasi, Ghana; \\ mensinfo@gmail.com \\ 1 Department of Energy and Environmental Engineering, University of Energy and Natural Resources, \\ Sunyani, Ghana; csmoke@ymail.com \\ 1 Global Change Research Institute, Bělidla 986/4a, 603 00, Brno, Czech Republic; mensah.c@czechglobe.cz \\ 2 Department of Horticulture, Kwame Nkrumah University of Science and Technology, Kumasi, Ghana; \\ caleb.mensah@uenr.edu.gh \\ * Correspondence: calnumic@gmail.com; Tel.: +420 608294420 \\ + Current address: Faculty of AgricSciences, Mendel University, Brno, Czech Republic
}

\begin{abstract}
The key anthropogenic effects on climate include the changes in land use and emission of greenhouse gases into the atmosphere. Depletion of vegetation poses serious threat that speeds the process of climate change and reduces carbon sequestration by the environment. Thus, the preservation of natural environment in urban areas is an essential component of the garden city model, proposed by Sir Ebenezer Howard in 1898, to ensure ecological balance. Recent Landsat images showed that Kumasi does not have the required percentage of green vegetation as was stipulated in the garden city model on which the city was built. It was observed that most parts of Kumasi's green vegetation have been lost to built environments. This study was conducted to assess the impact of urbanization on the garden city status and its effect on the micro-climate of the city. Significant changes in the vegetation cover of the city w as evaluated from Landsat-TM imagery and analysis of a long term climatic data of Kumasi carried out over a 55-year period (1960 to 2015). It was observed that, climatic conditions have slightly changed, as mean surface temperature of has increased by $1.2^{\circ} \mathrm{C} / 55$ years, due to the significant landuse changes from development of non-transpiring, reduced evaporative urban surfaces. However, the impact is not greatly felt due to the geographical location of the city on the globe despite the evidence of a considerable temperature change. Green vegetation conservation for the city is recommended as a top priority in future for city authorities and planners.
\end{abstract}

Keywords: Landuse change, Climate change; Garden city model; Green vegetation; Landsat; Urban heat island 


\section{Introduction}

The earth continues to undergo substantial changes due to the anthropogenic activities mostly through deforestation and urbanization. Recent development pattern of urban areas observed by the [56] found that, rapid urbanization is a critical problem with the resultant effect being destruction of much green vegetation to make way for the increasing population. Currently, roughly $80 \%$ of economic growth occurs in urban centers. According to a 2010 study from the United Nations Human Settlements Program, countries have more opportunities for economic growth through urbanization. This includes social services such as education and healthcare, reliable access to good drinking water, sanitation services, and electricity, massive industrial infrastructures and quality transportation hubs that are necessary for commercial development. Urban centers place substantially more pressure on natural resources than rural communities, given their population density and the attendant demands on water, agricultural, energy, and other resources. Recent study by [41] assessed the extent of deviation from of Kumasi from the garden city status by using archival recordds from Landsat satellite imagery. This study goes a step further to assess the impact of the urbanization on the climate of the city and the potential effect on the citizenry

The resultant expansion of urban land has significant climatic implications across all scales, since the continuous removal of natural land cover and the introduction of urban materials such as concrete, metal, etc changes the surface energy balance, resulting in an increase in sensible heat flux at the expanse of latent heat flux $[48,53]$. Consequently, highly evaporative surfaces have a Bowen ratio of approximately 0.1 and 1.0 for drier surfaces, due to the elevated temperatures over urban surfaces [21]. Surface characteristics such as albedo, roughness length or moisture availability control the energy balance partitioning of any surface [8]. Thus, gradually increasing the urban surface temperature

The climatic impact of urbanization has been quantified through the Urban heat island (UHI). This urban thermal environment affects residents' health, consumption and even productivity. Urban heat islands are mostly limited to a finite number of in situ temperature observations that describe the response instead of the forcing of repartitioned surface energy fluxes over urbanized surfaces [36]. Urban climate research requires good information on the land cover, which incorporates data on the urban land use changes and its associated surface energetic signature [48]. Satellite remote sensing is the most reliable and consistent way of monitoring land cover change associated with urbanization on the order of tens of kilometers. Thus, this study seeks to establish the retreat of green vegetation in Kumasi and its environs due to urbanization through analysis of spatial images from Landsat 4, 7 and 8 archives from the US Geological Survey, and further investigate its adverse effect on the climate from 1960 - 2015. The study is expected to serve as an upgrade upon earlier works by [38], who investigated the effect of global warming on Kumasi and Accra, and [17] who also investigated the impact of change in land use on the sources of drinking water in Kumasi. Change in land use within the city will affect the quality of drinking water and cause severe shortage in households if the right steps are not put in place by the city planners in this urbanization era. [45] also quantified the variability in distribution of vegetation, soil and ecosystem carbon storage in Kumasi due to recent urbanization

Mitigation and adaptation strategies are required by town planners to reduce the potential heat stress risk. Utilizing green infrastructure to lower the surface temperature, as described by $[15,18,28,42]$.

Further studies by [60] and [20] suggested ways through which urban planners could apply innovative solutions to improve upon the ventilation potential and heat release within the urban set-up. Other mitigation practices which take into consideration land-use planning strategies at early stages of the urban planning process are needed to reduce the effect of the heat stress $[31,35]$ 


\subsection{Urban Heat Island}

Urbanization leads to the expansion of the cities' boundaries and the densification of the urban tissue, with construction of tall building structures along relatively narrow roads/streets. This leads to gradual destruction to the vegetational cover, which plays a major role in energy balance and water cycle of the atmosphere. However, as a result of these constructions, the heat balance within the city is altered with air temperature within the densely built area being higher than in the surrounding rural areas. This phenomenon is generally referred to as 'Urban Heat Island' [44]. Studies on the relative warm temperatures characteristic of large cities in Europe as compared with the surrounding areas had been started in the 19th century [34]. The difference between the air temperature of city characterized with UHI and its surrounding areas is large at night and small during the day. Mostly, during variably or less cloudy days, urban surfaces are warmed faster by the absorption of solar radiation.

These built surfaces within the urban cities have high heat capacities that serve as a giant heat reservoir. Concrete can roughly hold about 2,000 times as much heat as an equivalent volume of air. At night, the situation is opposite with the absence of solar heating which inhibits atmospheric convection and stabilizes the urban boundary layer. This causes an inversion layer, which traps the air near the urban surface and warms the surface air, creating warmer nighttime air temperatures within the urban city [58]. The thermal difference coupled with heat produced from fossil fuel burning of vehicles, industries and houses contribute to the Urban Heat Island effect. This study and a previous study by [38] demonstrated the rise in daily night time temperatures in Kumasi as a result of urbanization. However, these difference in temperature could be higher for other cities with respect to topographical location and other meteorological conditions. The effect of cloud cover on daytime and nighttime temperatures were not determined for the area under study since no cloud cover data was analyzed

\section{Methodology}

\subsection{Study Area}

Kumasi is the second largest city in Ghana and is the commercial, industrial and cultural capital of the Ashanti Kingdom since 1695 [40]. Kumasi is approximately 500 kilometres (300 mi) north of the Equator and 200 kilometers north of the Gulf of Guinea and strategically located in south-central Ghana and all major roads converge at the city center. The city is geographically located in the moist semi- deciduous part of the South- East ecological zone of Ghana and within the tropical rain forest belt of West Africa, with average elevation of about 853 feet above the mean sea level [3]. The city has an aggregate area of roughly 254 square kilometers $\left(\mathrm{Km}^{2}\right)$ and comprises 10 sub-metropolitan areas, namely; Manhyia, Tafo, Suame, Asokwa, Oforikrom, Asawase, Bantama, Kwadaso, Nhyiaeso and Subin [39]

Kumasi is one of the few cities in Africa that enjoyed the implementation of the garden city model from its colonial masters who were the British. Following the defeat of the Ashanti's in a war by the British merchants in 1896, the whole city was raised down and rebuilt at the same location by the British [52]. The 1945 advancement planning which was made by Maxwell Fry and Jane Drew apportioned significant spaces for greenery. They took after the garden city model which was extremely renowned around that time. Samples of such spaces in Kumasi in that period were urban parks, greenhouses, trees, forests, and green belts. Resulting improvements of the city took after comparable example with much green spaces been protected in the city's physical scene. This circumstance made the city to pick up the honor the garden city of West Africa in the 1960s [51] 
107

\subsection{The Garden City Model of Kumasi}

By mid- Nineteenth century, mechanical developments together with monetary and social conditions had led to the acceleration of industrialization in Western Europe especially in Great Britain. The effect was mass movement of people into urban areas which brought lots of congestion and made these cities vulnerable to harmful conditions [12]. Sir Ebenezer Howard (1850 - 1928) in his known publication of 1898, titled 'To- Morrow: A Peaceful Path to Real Reform', explained how big cities could live harmoniously together with nature. This introduced the garden city movement. Lentchworth Garden City was the first garden city built from this concept in 1903. The greenery enclosure city model put forward by Howard in 1898 through his published work which was later updated in 1902, was to address the undesirable ways of life in urban cities, and how nature could be incorporated in town planning to produce a third magnet (garden city) that will give man trust and life [24]

With the Greenhouse city model, the urban communities designed with the wide open magnificent spaces of nature could attract individuals to live in them, whiles preserving nature [10]

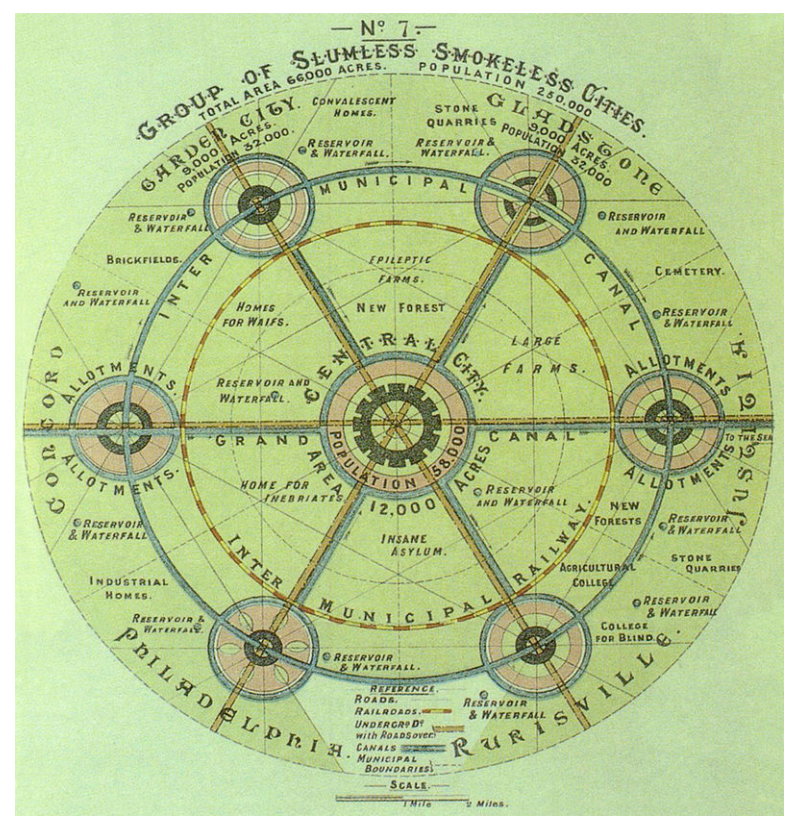

Figure 1. The Garden city concept by Sir Ebenezer Howard: Source [26] 


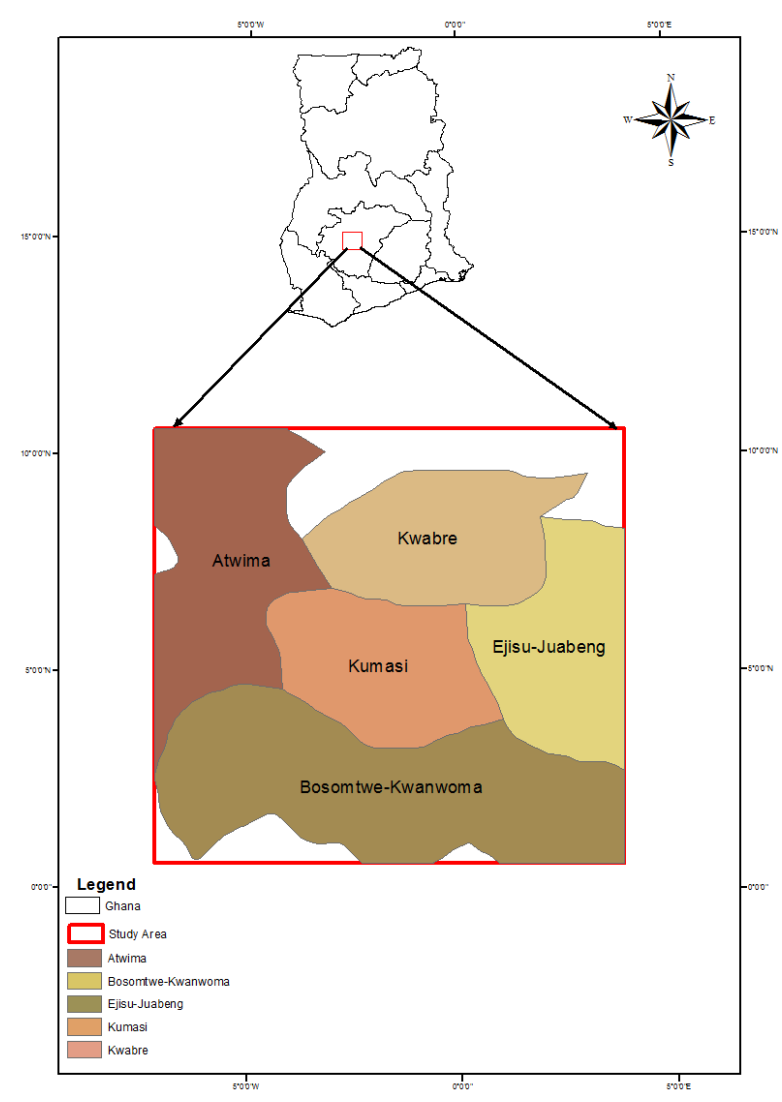

Figure 2. Map of Kumasi showing its surrounding towns 
Earlier studies by [2], reveals the beautiful greenery scenery that earned Kumasi the 'Garden city of West Africa'. Following the architectural designs of Maxwell Fry and Jane Drew in 1945, Kumasi had an eminent green belt (330 yards wide), with waterway tributaries that transected the city through its neighbourhoods including Atonsu, Kaase, Bantama and Aboabo [13]. These green spaces were characterized with several parks and gardens that were used for different purposes to fulfill the recreational needs of the individuals and further beautification of the city. There were five urban parks situated at vantage points. These were the Kejetia Park (Adehyeman gardens), Suntreso Park (at the premises of the premises of Department of Parks and Gardens), park at "Amakom" (now Kumasi Children's Park), Fante Newtown Park, and Kumasi Zoological Gardens (Kumasi Zoo). The Suntreso Park was known for containing a corridor passage like the English parks around then as stated by [16]. After these parks, it was seen that few different parks and gardens were made to serve the developing population of Kumasi. The remarkable ones among them were Abbey's Park, Jackson Park, Prince of Wales Park, Para Gardens and Kumasi Race Course. Others were the Kotoko Park (otherwise called Cricket) behind the Manhyia Hospital; the Addo's Park behind the Manhyia Palace; the Dogo Moro Park at "Asawase"; and the Rivoli Park at "Bantama" [4]. Driving or walking through the streets of Kumasi which full of vegetation was a pleasure to look as one will watch a lovely view of finished urban trees and gardens at the focal business region

\subsection{Data}

The spatial imageries were obtained from Landsat 4, 7 and 8 archives from the U.S Geological Survey (USGS). The table1 shows the summary of the three data sets used for the study, its source and date of acquisition. These images gave simple visuals distinguishing proof and real data on the progressions that have occurred in the green vegetation of the study area

Table 1. Summary of the datasets used in the analysis

\begin{tabular}{lcccccc}
\hline Satellite & Sensor & $\begin{array}{c}\text { WRS } \\
\text { Path/Row }\end{array}$ & $\begin{array}{c}\text { Date } \\
\text { Acquisition }\end{array}$ & $\begin{array}{c}\text { Spatial } \\
\text { Resolution }\end{array}$ & $\begin{array}{c}\text { Spectral } \\
\text { Resolution }\end{array}$ & Source \\
\hline Landsat 4-5 & TM & 195/055 & 20th January 1986 & $30 \mathrm{~m}$ & 8 bands & Earthexplorer.org \\
Landsat 7 & TM & 195/055 & 31st January 2007 & $30 \mathrm{~m}$ & 8 bands & Earthexplorer.org \\
Landsat 8 & TM & 195/055 & 15th January 2015 & $30 \mathrm{~m}$ & 11 bands & Earthexplorer.org \\
\hline
\end{tabular}


Climatic data collected from Ghana Meteorological Agency (GMet) was also used to assess the change in climatic conditions over the city. GMet like any other meteorological agency under the World Meteorological Organization (WMO), uses WMO's standards in its rainfall measurements. However, minor inconsistencies in the measurements due to instrumental or observational error could be introduced in the climate data analysis, which are quite neglegible [43]. This information accumulated much data to build up a chain of confirmation about the present condition of the green vegetation of Kumasi

\subsection{Data Analysis}

The Landsat imageries were analyzed using ArcGIS 10.4.1, ENVI 4.7, and MS Excel

\subsubsection{Image Processing and Classification}

Analysis of the land cover changes was done by processing three different satellite images geometrically to its local coordinate system. The imageries were georeferenced that is, by geometrically correcting the images to the local coordinate system using the Universal Transverse Mercator (UTM) projection (WGS 1984 UTM Zone 30N) in ArcMap 10.4.1

Also before the image classification was done, the images were pre-processed. These include radiometric and atmospheric corrections which are very essential in every remote sensing analysis due to distortions the images contain [6]. Radiometric correction is the process to reduce the degree of spectral differences emanated from the sensor leading to the images been distorted. Some of these distortions include atmospheric haze, scan lines and stripping [6]

The Landsat 7 TM developed a faulty scan line corrector on May 2003 which led to the scan lines seen in the 2007 imageries [6]. This fault was corrected and updated to Landsat 8 hence; images from the period the fault was detected to 2014 have some scan lines in them. The scan lines were removed from the imagery using the gap-fill extension in ENVI 4.7. Figure 5 shows the images with and without scan lines. Atmospheric correction is also done to remove the atmospheric haze such as clouds caused by the variations in the atmospheric conditions between the dates the images were obtained. There has not been any method to completely remove the haze in the images; however, this can be minimized using ENVI 4.7.

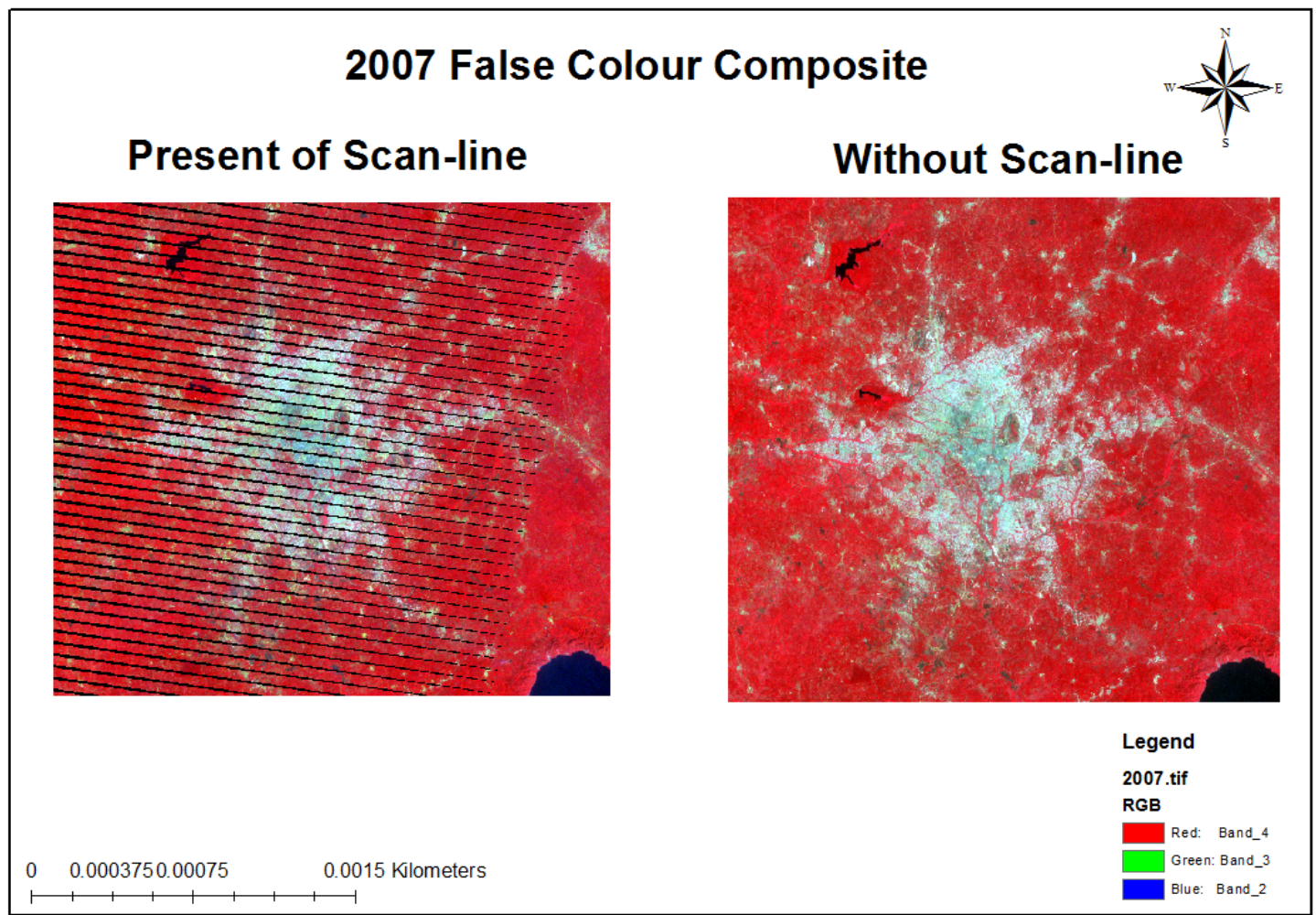


Remotely sensed data helped in providing information required for assessing the ecosystems' conditions through land cover mapping [5]. Land cover mapping mimicked the earth surface by delineating the different features that exist in their natural environment, using the image classification technique. For the purpose of this study, forest refers to areas covered with trees (either deciduous or evergreen), built-up areas refer to areas with residential or commercial structures and water bodies refer to areas covered by rivers, ponds, dams, etc.

Image Classification method was done for the three images using supervised classification techniques in ArcMap 10.4.1. In this case the training samples were selected based on the reflectance or the spectral characteristics of the classes. This technique gives more accurate results with a higher accuracy than the unsupervised technique [55]. The supervised classification was carried out using Maximum Likelihood Algorithm in ArcMap and selection of the training areas were based on the ground truth points obtained from google earth

\subsection{Image Enhancement and Accuracy Assessment}

Image enhancement was used to improve the quality of the imagery to make it look more suitable for analysis. The visibility of the imagery, mostly known as colour composite was established using the Landsat bands 432 (i.e. Near-Infrared, Red and Green), this was to obtain a false colour composite. The false colour composite is mostly used in vegetation analysis because plants mostly reflect highly in infrared but emits green colour as seen with the naked eyes. A deep forest reflects in deep red, agriculture in light green, built-up areas in cyan blue, soils vary from dark to light brown and water appears very dark in colour [25]

Accuracy assessment was carried out to determine the feasibility of the classified images depending on the level of acceptance of error in the imagery. This is very essential for any classified imagery since all classified images are assumed to be inaccurate to only be used as a decision-based tool. This also served as a guide for the map's quality and reliability. Hence, the accuracy assessment of these classified images were calculated using the Kappa coefficient statistics, $\mathrm{K}$ (which is the measure of the level of agreement of the classified image with the reference data) and the error matrix. Thus, a K $>0.80$ indicates a strong agreement of the class assessed. Whiles a $\mathrm{K}$ between 0.40 and 0.80 showed a good agreement, and $\mathrm{K}<0.40$ showed a poor agreement [27]

In this study a reference data consisting of 90 text pixels was generated based on a rule of thumb. The rule of thumb states that, there should be 10 times the number pixels for each class as there are all classes. In this case, three (3) classes were identified hence each class contains 30 text pixels with a total 90 text pixels all the three classes (Maps \& GIS Library, 2014). This was done in ArcMap 10.4.1 and later exported to MS Excel to further determine the kappa matrix (k), the overall accuracy, commission error (user's accuracy) and omission error (producer's accuracy). Overall accuracy is the total accuracy of the classified images. Commission error (user's accuracy) on the other hand is the probability of a specific class that is incorrectly classified, whiles Omission error (producer's accuracy) is the probability of a specific class to be incorrectly classified in the reference data or ground. The formulae used in determining the kappa coefficient, the overall accuracy, user's and producer's accuracy respectively; are given below respectively;

$$
\begin{aligned}
& K=\frac{\sum_{i=1}^{\gamma} X_{\mathrm{ii}}-\sum_{i=1}^{\gamma}\left(X_{\mathrm{i}+} X x_{+1}\right)}{N^{2}-\sum_{i=1}^{\gamma}\left(X_{\mathrm{i}+} X x_{+1}\right)} \\
& \text { Overallaccuracy }=\frac{\text { Totalnumberof pixelscorrectlyclassified }}{\text { Totalnumberofclassifiedcells }} \times 100 \\
& \text { User'saccuracy }=\frac{\text { Totalnumberofcorrectlycell(row) }}{\text { Totalnumberof pixelinagivenclass }} X 100 \\
& \text { Producer'saccuracy }=\frac{\text { Totalnumberofclassifiedcells }(\text { column })}{\text { Totalnumberofclassifiedpixel }(\text { column })} X 100
\end{aligned}
$$


208

209

Where $\mathrm{N}$ is the total number of observations in the matrix, $\mathrm{r}$ is the number of rows in the matrix, $\mathrm{x}_{\mathrm{ii}}$ is the number of observations in row $\mathrm{i}, \mathrm{x}_{+\mathrm{i}}$ is the total for row $\mathrm{i}$ and $\mathrm{x}_{+\mathrm{i}}$ is the total for column $I$ [27]

\subsection{Change Detection Technique}

This is the technique used to determine the changes that have occurred in a particular place over a period of time. This process involves the use of multi-spectral and multi-temporal data set which is used to discriminate between the changed areas [37]. The classified images were used in this study to determine the cover change, annual rate of change and the percentage annual rate of change within the years under the study, 1986-2007, 2007-2015 and 1986-2015 respectively. The attribute table of the changed maps were exported to MS Excel based on the following formulae to determine the change detection matrix

$$
\begin{aligned}
& \text { PercentageChange }=\frac{\text { Area }_{\mathrm{i} Y e a r x+1}-\text { Area }_{\mathrm{i} Y e a r x}}{\sum_{i=1}^{n} A r e a_{\mathrm{i} Y e a r x}} \\
& \text { Annualrateof change }=\frac{\text { Area }_{\mathrm{i} Y e a r x+1}-\text { Area }_{\mathrm{iYearx}}}{t_{\text {Years }}} \\
& \text { PercentageAnnualrateof change }=\frac{\text { Area }_{\mathrm{i} Y e a r x+1}-\text { Area }_{\mathrm{iYearx}}}{\sum_{i=1}^{n} \text { Area }_{\mathrm{i} Y \mathrm{Yarx}} x t_{\text {Years }}}
\end{aligned}
$$


Where; Area $_{\mathrm{iYearx}+1}=$ area of land cover(i) for the subsequent year of the following date, Area $\mathrm{iYearx}_{\mathrm{Y}}=$ area of land cover(i) for the initial year, $\sum_{i=1}^{n} A$ Area $a_{\mathrm{i} \text { Yearx }}=$ the sum of the land cover area for the initial year, $\mathrm{t}_{\text {Years }}=$ the number of years between the initial year and subsequent year [30]

\subsection{Climatic Data Analysis}

Analysis on the long term temperature and rainfall data over the 55years period (1960 - 2015) over Kumasi and two other towns (Konongo and Ejura) was used. These climatic variables were used because of their tendency to reveal changes in extreme values during the period of study. Annual maximum and minimum temperature and precipitation analyzed over the period was used to establish the historical trends using linear regression equation with inter-annual variability assessed. A 10- year temperature anomaly was used to compare for both the maximum and minimum temperatures over Kumasi, Konongo and Ejura

This comparison of the temperature over Kumasi with that of other towns like Konongo and Ejura was made to investigate the presence of the urban heat island effect in Kumasi. Also the urbanization effect of the city is expected to affect the variability of precipitation. The linear trend of precipitation is also calculated using the data measured from the Ghana Meteorological Agency over the period of study

\section{Results and Discussion}

\subsection{Land Use Change Analysis}

Three land cover classes were identified for the land cover classification done to determine the land use and land cover changes that occurred between 1986, 2007 and 2015 respectively within the study area. These include the Forest, Built-up areas and Water body. The classified land cover maps for this study are shown in figure 4

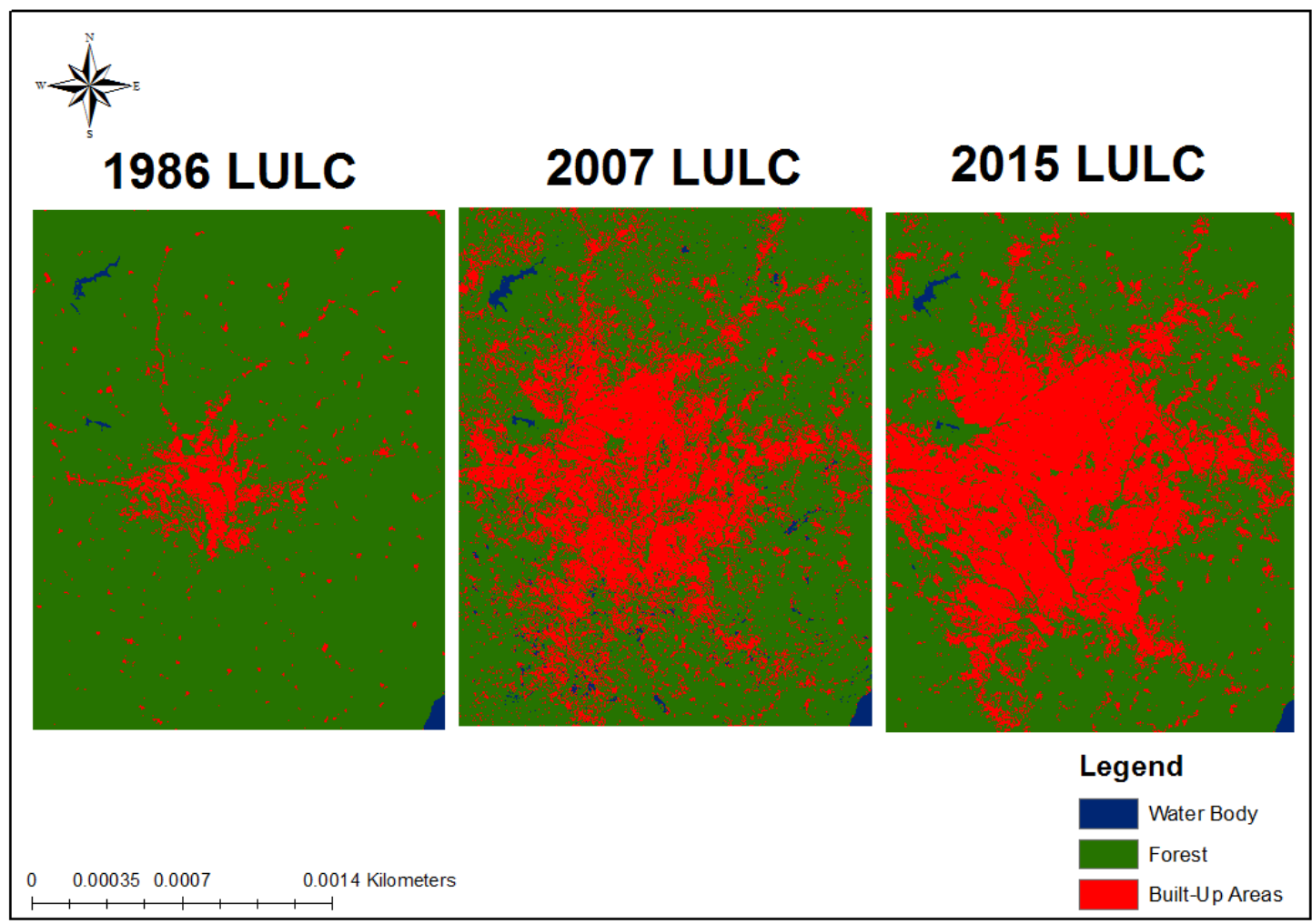

Figure 4. Classified Land Cover Maps for 1986, 2007 and 2015 
Acquiring a Landsat images free from cloud cover in Africa especially is a major issue. This is also the reason why the analysis was not able to cover the whole region. However, the image obtained from Landsat for this study had a minimal cloud cover and those containing the clouds too were seen at a small portion with an insignificant effect to the work

In 1986 the land cover was mainly dominated with forest, however as population increased the land cover also started changing, as seen in 2007 and 2015 which were mostly dominated with built-up areas. Also from figure 4, the built-up areas were mainly dominated at the the central portion of the region. This shows that most of the activities are seen in the central part of the region as people travel from all walks of life in search of greener pastures in this area. Water body also started increasing from 2007 to 2015, indicating that urbanization has a serious impact on the environment. Development in urban areas involves covering the ground with artificial surfaces, therefore increasing the amount of surface runoff as compared to infiltration, evaporation and transpiration which directly affects the hydrological cycle. This is because, surface runoff travels faster on a hard smooth surfaces than it does over a natural surface. However, increase in surface runoff increases the total volume of water reaching the river soon after the rain leading to less been infiltrated into the soil and also causing flooding

\subsection{Accuracy Assessment}

The accuracy assessment of this study was determined based on the equations 1-4 above to compare the classified results with the ground truth data. This was analysed using ArcMap and later exported to Microsoft Excel for further analysis which cannot be done in ArcMap. The table2 shows the error matrix and the total accuracy report for 1986 classified image. The image classified in 1986, had an overall accuracy of $91.1 \%$ and kappa coeffiecient of 0.87 , indicating that $87 \%$ of the classified image is in agreement with the reference data used for assessment

In 1986, as shown in table2, water bodies recorded the highest producer accuracy, that is $100 \%$, followed by forest (91.43\%) whiles built-up areas recorded the least $(83.39 \%)$. This indicates that the class "Water" had the highest probability of being correctly classified. Also for the user's accuracy, built-up areas and forest had the highest that is $100 \%$ respectively, followed by water body water body $75.76 \%$ having the least probability. This indicates that, the forest and built-up areas had the highest probability of what was classified on the map actually representing exactly what is on ground

Table 2. Accuracy Assessment for 1986 Land Cover Map

\begin{tabular}{ccccccc}
\hline $\begin{array}{c}\text { Class } \\
\text { Names }\end{array}$ & $\begin{array}{c}\text { Water } \\
\text { Body }\end{array}$ & Forest & $\begin{array}{c}\text { Built-Up } \\
\text { Area }\end{array}$ & $\begin{array}{c}\text { Classified } \\
\text { Total }\end{array}$ & $\begin{array}{c}\text { Error } \\
\text { Commission (\%) }\end{array}$ & $\begin{array}{c}\text { User's } \\
\text { Accuracy (\%) }\end{array}$ \\
\hline $\begin{array}{c}\text { Water } \\
\text { Body }\end{array}$ & 25 & 3 & 5 & 33 & 24.24 & 75.76 \\
$\begin{array}{c}\text { Forest } \\
\text { Built-Up } \\
\text { Area }\end{array}$ & 0 & 32 & 0 & 32 & 0 & 100 \\
$\begin{array}{c}\text { Reference } \\
\text { Total }\end{array}$ & 0 & 0 & 25 & 25 & 0 & 100 \\
\hline $\begin{array}{c}\text { Error } \\
\text { Commission(\%) } \\
\text { Producer's }\end{array}$ & 0 & 85 & 30 & 90 & - & - \\
Accuracy(\%) & 100 & 91.43 & 83.33 & & $\begin{array}{c}\text { Overall } \\
\text { Accuracy(\%) } \\
\text { Kappa } \\
\text { Coefficient(\%) }\end{array}$ & 0.87 \\
\hline
\end{tabular}


In 2007 , the overall accuracy recorded was $98.9 \%$ with a kappa coeffient 0.99 . Thus, $99 \%$ of the classified image was in agreement with the reference data used for analysis. The details of the error matrix for the classified image can also be seen in table3. In this year the highest producer's accuracy recorded were water body (100\%) and forest (100\%), whiles built-up areas recorded the least (96.75\%). This however indicates that water body and forest had the highest probability of been correctly classified. This shows that, what was been classified represents what is actually on the ground

Table 3. Accuracy Assessment for 2007 Land Cover Map

\begin{tabular}{|c|c|c|c|c|c|c|}
\hline $\begin{array}{c}\text { Class } \\
\text { Names }\end{array}$ & $\begin{array}{l}\text { Water } \\
\text { Body }\end{array}$ & Forest & $\begin{array}{c}\text { Built-Up } \\
\text { Area }\end{array}$ & $\begin{array}{c}\text { Classified } \\
\text { Total }\end{array}$ & $\begin{array}{c}\text { Error } \\
\text { Commission (\%) }\end{array}$ & $\begin{array}{c}\text { User's } \\
\text { Accuracy (\%) }\end{array}$ \\
\hline $\begin{array}{l}\text { Water } \\
\text { Body }\end{array}$ & 25 & 0 & 1 & 26 & 3.85 & 96.15 \\
\hline Forest & 0 & 35 & 0 & 35 & 0 & 100 \\
\hline $\begin{array}{l}\text { Built-Up } \\
\text { Area }\end{array}$ & 0 & 0 & 29 & 29 & 0 & 100 \\
\hline $\begin{array}{l}\text { Reference } \\
\text { Total }\end{array}$ & 25 & 35 & 30 & 90 & - & - \\
\hline $\begin{array}{c}\text { Error } \\
\text { Commission(\%) }\end{array}$ & 0 & 0 & 3.33 & & $\begin{array}{c}\text { Overall } \\
\text { Accuracy }(\%)\end{array}$ & 98.89 \\
\hline $\begin{array}{c}\text { Producer's } \\
\text { Accuracy }(\%)\end{array}$ & 100 & 100 & 96.67 & & $\begin{array}{c}\text { Kappa } \\
\text { Coefficient }(\%)\end{array}$ & 0.99 \\
\hline
\end{tabular}

In 2015 , the overall accuracy recorded is $85.56 \%$ with a kappa coeffient 0.78 , indicating a good agreement with reference data. The details of the error matrix for the classified image can be seen in the table 4

In this year, built-up areas recorded the highest producer's accuracy of $91.43 \%$ followed by forest and water body recording $83.33 \%$ and $80 \%$ respectively. This however indicates that forest and water body had the highest probability of been correctly classified. This shows the percentage level of what is been classified representing what is actually on the ground. Also from the previous years as shown from the table4, 2015 recorded the least overall accuracy and kappa coeffient though it falls within the accepted range. This is due dominance of the built-up areas with a higher reflectance within the research area

Table 4. Accuracy Assessment for 2015 Land Cover Map

\begin{tabular}{ccccccc}
\hline $\begin{array}{c}\text { Class } \\
\text { Names }\end{array}$ & $\begin{array}{c}\text { Water } \\
\text { Body }\end{array}$ & Forest & $\begin{array}{c}\text { Built-Up } \\
\text { Area }\end{array}$ & $\begin{array}{c}\text { Classified } \\
\text { Total }\end{array}$ & $\begin{array}{c}\text { Error } \\
\text { Commission (\%) }\end{array}$ & $\begin{array}{c}\text { User's } \\
\text { Accuracy (\%) }\end{array}$ \\
\hline $\begin{array}{c}\text { Water } \\
\text { Body }\end{array}$ & 20 & 5 & 0 & 25 & 20 & 80 \\
$\begin{array}{c}\text { Forest } \\
\text { Built-Up } \\
\text { Area }\end{array}$ & 5 & 25 & 3 & 33 & 24.24 & 75.76 \\
$\begin{array}{c}\text { Reference } \\
\text { Total }\end{array}$ & 25 & 30 & 35 & 90 & 0 & 100 \\
\hline $\begin{array}{c}\text { Error } \\
\text { Commission(\%) } \\
\text { Producer's }\end{array}$ & 20 & 16.67 & 8.57 & & $\begin{array}{c}\text { Overall } \\
\text { Accuracy(\%) } \\
\text { Kappa }\end{array}$ & 85.56 \\
Accuracy(\%) & 80 & 83.33 & 91.43 & & Coefficient(\%) & 0.78 \\
\hline
\end{tabular}


284

The overall accuracy for this study was not 100\% because of some few misclassifications of pixels which occurred in nearly all the classes. Most of these misclassifications can be attributed to the nature of the image used in terms of clouds and scan lines. Also difficulty in differentiation between the spectral reflectance between water body and forest since most of the water body were covered with trees and some are also found within forest. Using Landsat image with a low resolution makes it difficult as compared with high resolution images which are commercial

\subsection{Land Cover Change Detection Analysis due to Urbanization in Kumasi}

Change detection analysis shows the changes that have taken place within a given area at a particular period of time from 1986 to 2015. From the table5 and table6, from 1986-2007 most of the areas were converted to built-up areas by $2.23 \mathrm{ha}$ /year followed by water body $0.08 \mathrm{ha} /$ year whiles the forest cover reduced by 2.31 ha/year

Table 5. LULC Change Analysis from 1986 - 2007 (a)

\begin{tabular}{ccccc}
\hline Class & $\begin{array}{c}\text { LULC 1986 } \\
\text { Area } \\
\text { Names }\end{array}$ & $\begin{array}{c}\text { Cover } \\
(\%)\end{array}$ & $\begin{array}{c}\text { LULC 2007 } \\
\text { Area } \\
(\text { ha })\end{array}$ & $\begin{array}{c}\text { Cover } \\
(\%)\end{array}$ \\
\hline Water & 2.62 & 1.13 & 4.31 & 1.87 \\
Body & 218.84 & 94.63 & 170.42 & 73.69 \\
$\begin{array}{c}\text { Forest } \\
\text { Built-Up }\end{array}$ & 9.81 & 4.24 & 56.54 & 24.45 \\
Area & 231.27 & 100.00 & 231.27 & 100.00 \\
Total & & & & \\
\hline
\end{tabular}

Table 6. LULC Change Analysis from 1986 - 2007 (b)

\begin{tabular}{ccccc}
\hline Class & $\begin{array}{c}\text { Area } \\
\text { Change } \\
\text { (ha) }\end{array}$ & $\begin{array}{c}\text { LULC 1986 - 2007 } \\
\text { Cover } \\
\text { Change } \\
(\%)\end{array}$ & $\begin{array}{c}\text { Annual } \\
\text { rate of } \\
\text { Change(ha/yr) }\end{array}$ & $\begin{array}{c}\text { Annual } \\
\text { rate of } \\
\text { Change (\%/yr) }\end{array}$ \\
\hline Water & 1.70 & 0.73 & 0.08 & 0.03 \\
Body & -48.42 & -20.94 & -2.31 & -1.00 \\
$\begin{array}{c}\text { Forest } \\
\text { Built-Up } \\
\text { Area }\end{array}$ & 46.73 & 20.20 & 2.23 & 0.96 \\
\hline
\end{tabular}

Also from the table7 and table8, from 2007-2015, built-up areas increased by 1.14 ha/year, whiles water body and forest cover decreased by 0.21 ha/year and 0.92 ha/year respectively

Table 7. LULC Change Analysis from 2007 - 2015 (a)

\begin{tabular}{ccccc}
\hline Class & $\begin{array}{c}\text { LULC 2007 } \\
\text { Area } \\
\text { Names }\end{array}$ & $\begin{array}{c}\text { Cover } \\
(\%)\end{array}$ & $\begin{array}{c}\text { LULC 2015 } \\
\text { Area } \\
\text { (ha) }\end{array}$ & $\begin{array}{c}\text { Cover } \\
(\%)\end{array}$ \\
\hline Water & 4.31 & 1.87 & 2.61 & 1.13 \\
Body & 170.42 & 73.69 & 163.04 & 70.50 \\
$\begin{array}{c}\text { Forest } \\
\text { Built-Up }\end{array}$ & 56.54 & 24.45 & 65.63 & 28.38 \\
Area & 231.27 & 100.00 & 231.27 & 100.00 \\
Total & & & & \\
\hline
\end{tabular}


Table 8. LULC Change Analysis from 2007 - 2015 (b)

\begin{tabular}{ccccc}
\hline Class & $\begin{array}{c}\text { Area } \\
\text { Change } \\
\text { (ha) }\end{array}$ & $\begin{array}{c}\text { LULC 2007 - 2015 } \\
\text { Cover } \\
\text { Change } \\
(\%)\end{array}$ & $\begin{array}{c}\text { Annual } \\
\text { rate of } \\
\text { Change(ha/yr) }\end{array}$ & $\begin{array}{c}\text { Annual } \\
\text { rate of } \\
\text { Change }(\% / y r)\end{array}$ \\
\hline Water & -1.71 & 0.74 & -0.21 & -0.09 \\
Body & -7.38 & -3.19 & -0.92 & -0.40 \\
$\begin{array}{c}\text { Forest } \\
\text { Built-Up } \\
\text { Area }\end{array}$ & 9.08 & 3.93 & 1.14 & 0.49 \\
\hline
\end{tabular}

297 It can be seen that there has been a tremendous change in the study area from 1986-2015 as shown in 298 table9 and table10. From this period there has been a continuous increase in built-up areas by 1.92 ha/year with an indirect decreasing in forest cover of $1.92 \mathrm{ha} /$ year and water body $0.21 \mathrm{ha} /$ year

Table 9. LULC Change Analysis from 1986 - 2015 (a)

\begin{tabular}{|c|c|c|c|c|}
\hline $\begin{array}{c}\text { Class } \\
\text { Names }\end{array}$ & $\begin{array}{c}\text { LULC } 1986 \\
\text { Area } \\
\text { (ha) }\end{array}$ & $\begin{array}{c}\text { Cover } \\
(\%)\end{array}$ & $\begin{array}{c}\text { LULC } 2015 \\
\text { Area } \\
\text { (ha) }\end{array}$ & $\begin{array}{c}\text { Cover } \\
(\%)\end{array}$ \\
\hline $\begin{array}{l}\text { Water } \\
\text { Body }\end{array}$ & 2.62 & 1.13 & 2.61 & 1.13 \\
\hline Forest & 218.84 & 94.63 & 163.04 & 70.50 \\
\hline $\begin{array}{c}\text { Built-Up } \\
\text { Area }\end{array}$ & 9.81 & 4.24 & 65.63 & 28.38 \\
\hline Total & 231.27 & 100.00 & 231.27 & 100.00 \\
\hline
\end{tabular}

Table 10. LULC Change Analysis from 1986 - 2015 (b)

\begin{tabular}{ccccc}
\hline Class & $\begin{array}{c}\text { Area } \\
\text { Change } \\
\text { (ha) }\end{array}$ & $\begin{array}{c}\text { LULC 1986 - 2015 } \\
\text { Cover } \\
\text { Change } \\
(\%)\end{array}$ & $\begin{array}{c}\text { Annual } \\
\text { rate of } \\
\text { Change(ha/yr) }\end{array}$ & $\begin{array}{c}\text { Annual } \\
\text { rate of } \\
\text { Change }(\% / y r)\end{array}$ \\
\hline Water & 0.00 & 0.00 & -0.21 & 0.00 \\
$\begin{array}{c}\text { Body } \\
\text { Forest }\end{array}$ & -55.80 & -24.13 & -1.92 & -0.83 \\
$\begin{array}{c}\text { Built-Up } \\
\text { Area }\end{array}$ & 55.81 & 24.13 & 1.92 & 0.83 \\
\hline
\end{tabular}


300 Figure 5 shows the graphical trend of the land cover changes from 1986 - 2015 for all the classes at 301 different period as seen in table 5 to table 10

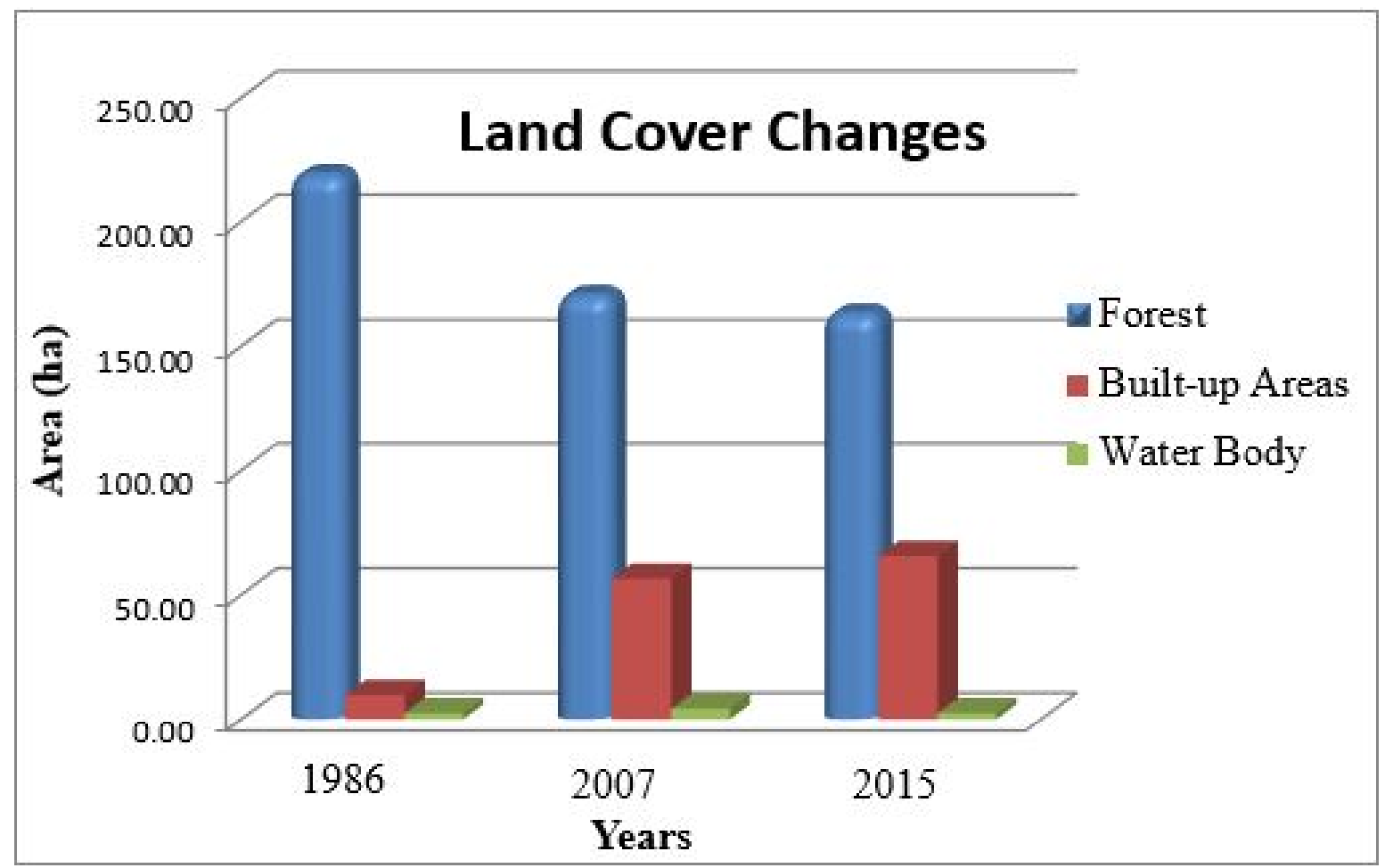

Figure 5. Graphical Representation of the Land Cover Changes 
Land cover change detection was analyzed using the post classification change detection approach which deals with the comparison of two independently classified land cover maps from two different dates. According to studies by [33], the causes of the land use land cover change highlights the concerns of the research agenda on the global environmental changes several decades ago. This is due to the fact that land cover changes influence climate change, ecosystems and the ability of biological systems to support human needs in terms of ecosystem goods and services

In this study, the main land covers are the forest, water body and built-up areas. The change detection from 1986 to 2015 indicates the decreasing rate of the forest cover with a slight increase in water body over a period of time with also increasing rate in built-up areas. This helped showed the trend of the forest cover change as the years increased in the study area. In this case the annual rate of change occurring in the study area for the period of 1986 to 2015 was calculated. The highest forest cover loss was recorded in 1986 to 2007 , of about $20.94 \%$ of the total area experiencing forest loss. $20.24 \%$ of the forest area was converted into built-up area which led to the forest cover loss within this period. This forest loss can be attributed to the weak law enforcement and less control mechanism within this period. Moreover, this change may be attributed to population increase, hence the demand for accommodation. Also land owners sell their land mostly agricultural lands and forest areas to housing or real estate developers due to the huge amount of money paid by the developers

Earlier study by [32], on the loss of the green vegetation to the built- up areas, attributed the main cause to the conversion of these places to houses and buildings to meet the accommodation needs of the rising population in Kumasi a result of urban migration. Increased farming activities and uncontrolled illegal mining activities led to the clearing and destruction of the green vegetation. These classified Landsat imageries showed how the city had rapidly extended outward showing a high occurence of urban sprawl. Other studies by [11] and [54], over Kumasi affirmed this by explaining how the urban sprawl had taken up a large area of the city's green vegetation. Consequently, the large green vegetation area that used to exist over the city has drastically been reduced, casting a negative image on the 'Garden city' of Kumasi

\subsection{Population Growth of the City}

From the 2010 Population and Housing Census conducted by the Ghana Statistical Service, Ashanti Region recorded a population of 4,780,380 in 2010 as compared to the 3,612,950 in 2000, with the Kumasi Metropolis recording a population of 1,730,249 in 2010 as against 1,170,270 in 2000. The statistics (as shown below) shows an intercensal growth rate of $8.76 \%$ in population for Kumasi in 2000 and a $3.91 \%$ further growth rate for 2010 . Kumasi is also home to about $39.49 \%$ of the total population in the Ashanti Region and about $7.65 \%$ in Ghana. These statistical records show how populated the city continues to be, and the need for its expansion to accommodate the growing population [22]

The uncontrolled extension of the city fundamentally through high rate of lodging advancements put much pressure on numerous nature reserves and destroys the rich green vegetation that had been protected throughout the years. The land area of Kumasi in 1950 was just $25 \mathrm{~km}^{2}$ but due to the quick urban sprawl, the city had extended outward to around $182 \mathrm{~km}^{2}$ in 1963 and as at 2011, the city has further extended past its limits to cover an area of approximately $254 \mathrm{~km}^{2}$ [50]. A comparable study by [7] over Melbourne (another garden city) showed that the city had greatly expanded due to urban sprawl. This also had a negative effect on the green vegetation or spaces which used to exist in the city 


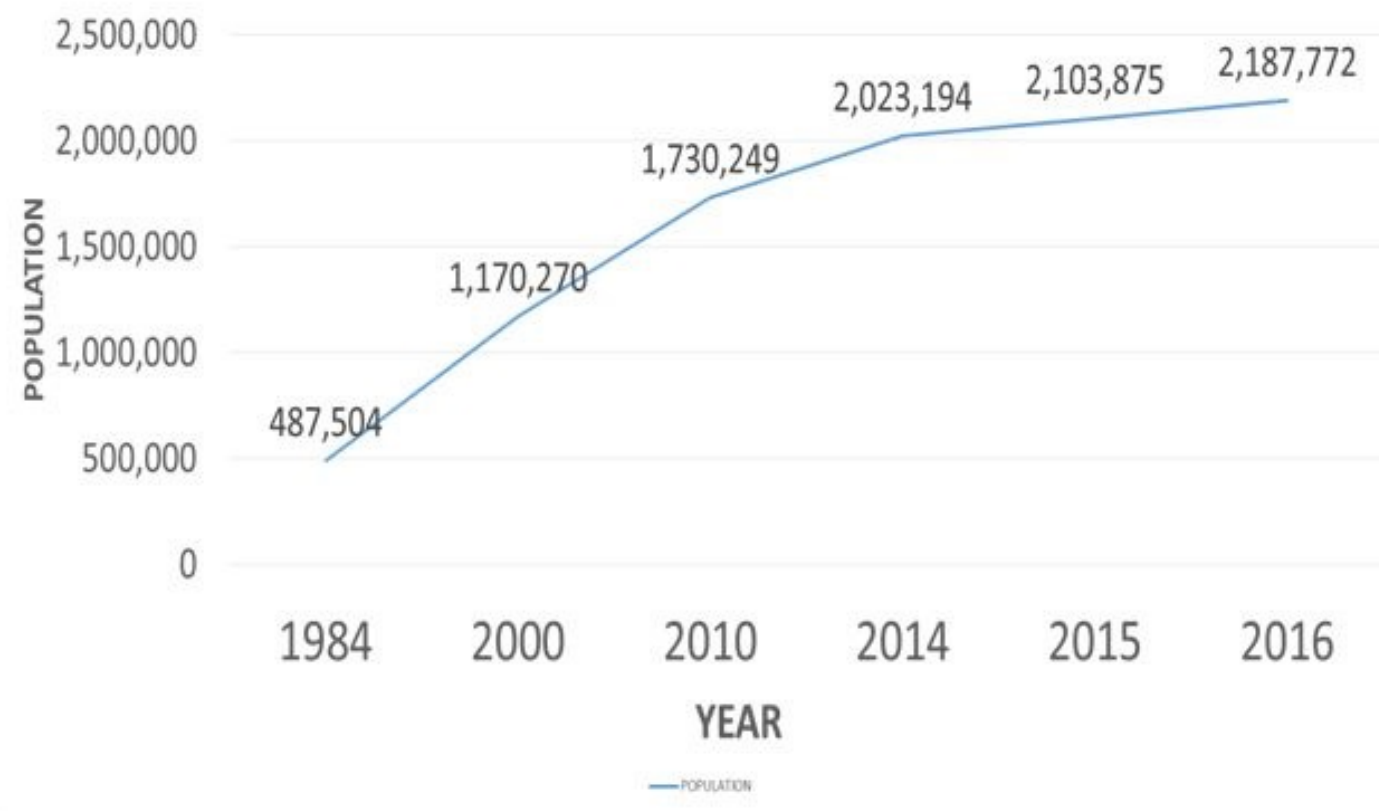

Figure 6. Population of Kumasi since 1984 (Source: Kumasi Metropolitan Assembly, 2016 
343 3.5. Micro- Climatic response to Urbanization 1960 - 2015

344 3.5.1. Temperature Trend

345 Figure7 shows the departure of the annual mean temperature from the average during 1960 - 1990 at ${ }_{346}$ Kumasi compared to two other surrounding towns (Konongo and Ejura), in the Ashanti region but

$34753 \mathrm{~km}$ and $100 \mathrm{~km}$ away from Kumasi respectively. These surrounding towns have a good considerable 348 green vegetation cover as compared to Kumasi. The linear increasing trend of the mean temperature 349 at Kumasi is $1.2{ }^{\circ} \mathrm{C} / 55$ years, with $1.0^{\circ} \mathrm{C} / 55$ years for Ejura and $0.2{ }^{\circ} \mathrm{C} / 55$ years for Konongo

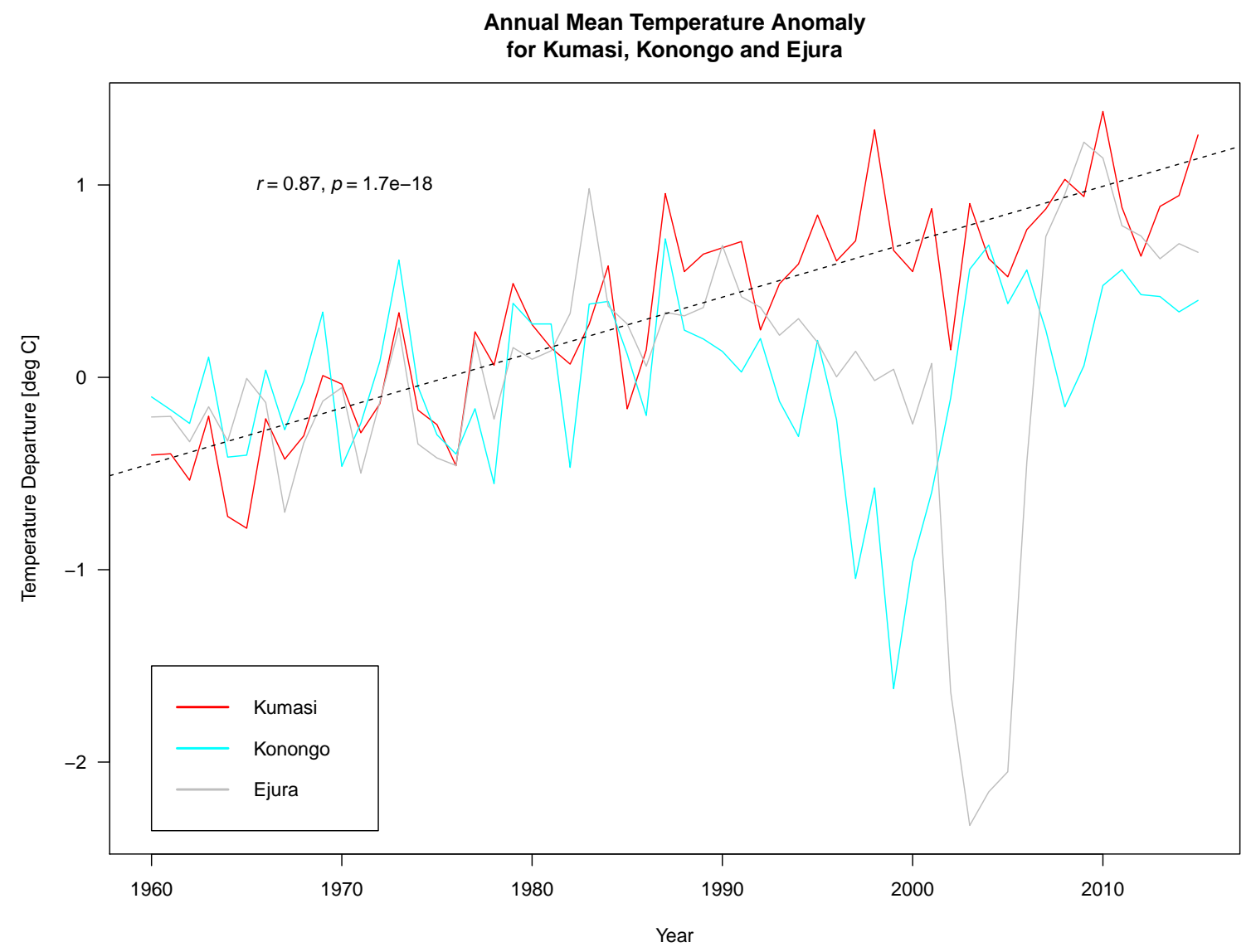

Figure 7. Mean Surface Temperature Departures for Kumasi, Konongo and Ejura 
The rate of increase of the daily minimum temperature at Kumasi $\left(1.55^{\circ} \mathrm{C} / 55\right.$ years) was slightly lesser than the rate of change for the daily maximum temperature $\left(1.78^{\circ} \mathrm{C} / 55\right.$ years), from $1960-2015$, showing a decreased daily range. The rapid urban warming of Kumasi differs from that of other cities in Europe and North America, with recent rise in temperatures not conspicuous in spite of the existence of heat islands [29,49]. It was observed from the analysis that 1965 was relatively the coldest year with an average annual temperature of $25.25^{\circ} \mathrm{C}$ within the period of study, whilst 2010 recorded relatively the warmest average mean temperature of $27.41^{\circ} \mathrm{C}$ within the period of study too

A possible explanation for this difference and increase in temperatures as showed from both the mean surface temperature analysis for Kumasi and its surrounding cities has been the significant change in landscape of Kumasi from the 'Garden city' model, which has also been supported by the analyzed Landsat images. This has been as a result of the rapid growth of the city with increase in population and built environments (homes and industries made up of impervious layers like concrete, black asphalt, bricks and stones)

The relatively hot season observed for Kumasi usually lasts from March to April with an average daily temperature of $32^{\circ} \mathrm{C}$. Whiles the relatively cool season also lasts from June to October annually, with average daily temperature of $28^{\circ} \mathrm{C}$. Further analysis showed that the maximum temperatures recorded for Kumasi within the hot period, especially for March showed a significant increase in temperature, with August also exhibiting a substantial rise in its minimum temperatures for the same period as shown in figure?? and figure?? respectively

Most studies done on urban heat islands have also established the warmth associated with cold seasons, when there is strong nocturnal inversion in rural areas, although there could also be some effects from topography and micro- scale weather effects [57]. The possibility of an urban bias in long-term temperature data is not only limited to large cities because heat islands can even occur for smaller cities with huge population. Ejura and Konongo were selected for this research because they were considered not to have been much influenced by urbanization and had a lesser population as compared with Kumasi. These two cities too have a greater percentage of green vegetation than Kumasi and are also found within the Ashanti region

Long- term temperature records from urban towns in Ghana have shown a substantial warming trend, especially for Kumasi and Accra [38]. Other non-weather microscale factors could be responsible for these observed temperature changes. For the case of Kumasi, construction of these built-up environment (buildings, roads, etc), have greatly contributed to the changes of these temperatures within the city. Some of these tall buildings erected within the city also decrease the exposure of the city to wind and upward heat diffusion, which also results in temperature rise

\subsubsection{Precipitation Trend}

Kumasi is situated in the wet semi-equatorial region of Ghana. The climate of the city is characterized by two rainfall seasons with annual mean rainfall between $1250 \mathrm{~mm}$ and $2000 \mathrm{~mm}$. The precipitation trend for the city within the 55- year period has also not changed much but show annual variation (figure8) 


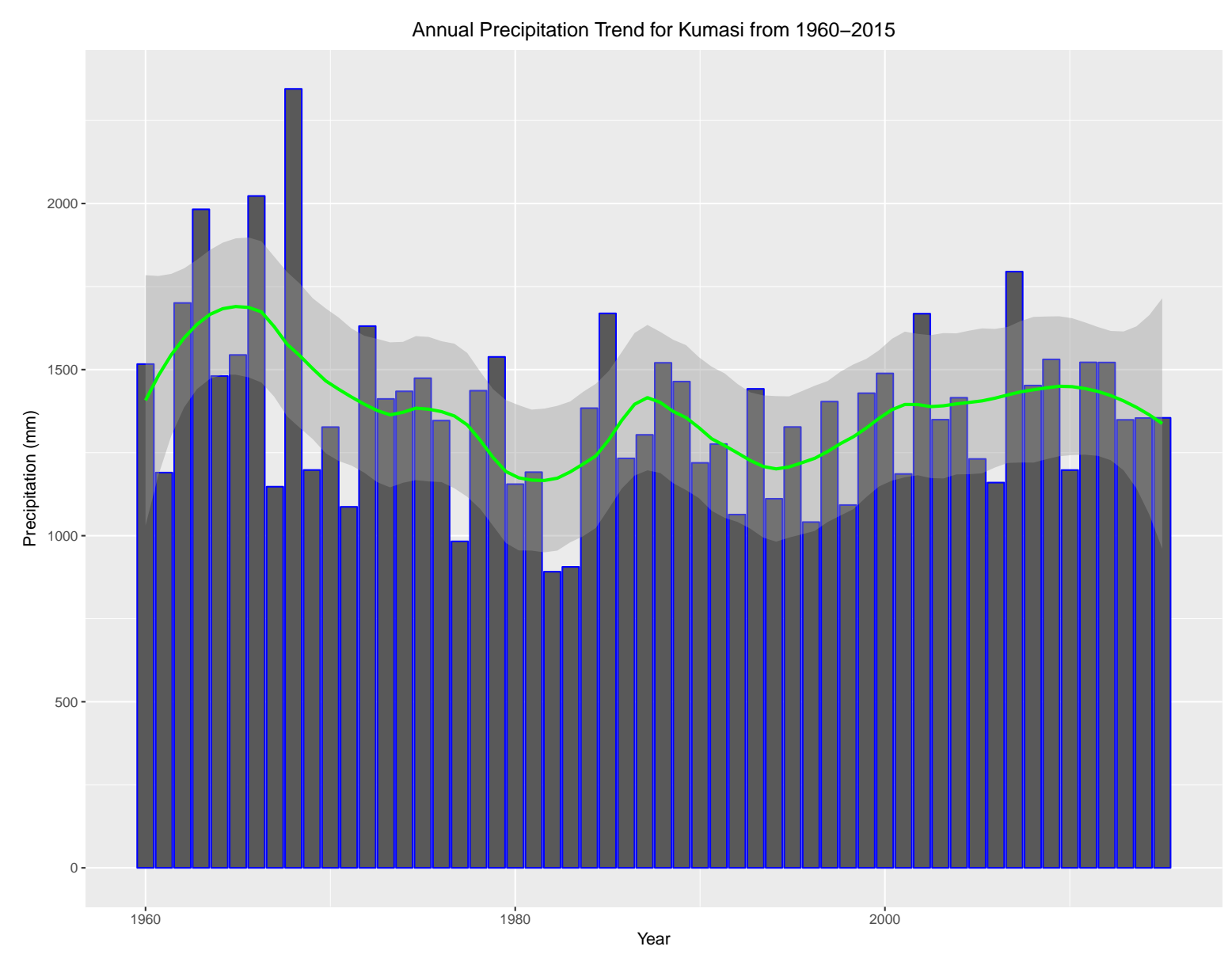

Figure 8. Annual Precipitation Observed over Kumasi from 1960 - 2015 
The analysis also shows that the relatively wet year for Kumasi was in 1966, with an annual mean rainfall amount of 2,345mm. Whiles, 1982 and 1983 recorded the least annual mean rainfall over the city. The dryness for the year was not associated with the urbanization but to the El Niño Southern Oscillation (ENSO) effect, which affected Ghana's rainfall season that year. The ENSO effect of 19821983 strongly affected most areas of the country causing severe droughts and famine [1]. However, variability in rainfall observed over the city is expected to affect the agricultural planning for farmers within the region, as shifts in the onset and length of the rainy season will have major impacts on crop production. Some rainy seasons have been observed to start late but end shortly, whiles other rainy seasons for some years experienced long dry spells that largely affected crop productivity or yield [43]

With most green parts of the city already lost to construction of buildings and traffic, leading to increase in temperature, other secondary effects on the local meteorology and change in the local wind patterns and humidity will vary strongly. Frequent variability in rainfall will lead to extreme weather conditions from drought to flood periods. The presence of vegetation cools the surrounding air through transpiration and enhances the evaporative cooling effect within the city [46]. Other studies have shown that large urban cities experiencing the urban heat effect are characterized by lower relative humidity than its surrounding areas due to the impervious surfaces, which results in a slightly lower heat index $[6,14,19]$. This causes reduced evapotranspiration and greater runoff, which results to higher temperatures but lower relative humidity [23]

\section{Conclusion and Recommendations}

This research utilized remote sensing data to identify the land use land cover changes between 1986 and 2015 within the study area. The trend of the forest cover loss within the study area could be attributed to the conversion of the forest cover to the expansion of built-up areas. This has significantly increased the water body as artificial surfaces are created in the urban areas, hence leading the high runoff generated with less infiltration rate. Also most of the water body find their source from these mountainous and forested areas, however resulting in some water body within the forest area getting dried up due to deforestation. Ecosystem activities are interlinked together hence the activity of one can directly or indirectly affect the ecosystem. Therefore, the conversion scenarios are very keen for the stakeholder to better understand the environment and for sustainable implementations. Forest areas can be protected from invasion by people leaving around for sand winning activities, farming and built-up operations

Most researches have indicated that the use of RS data and GIS technique is a valuable tool in analyzing, locating and predicting the land cover change. RS data could aid in the forest cover change detection and also help identify areas that are under high risk of invasions. This study has shown that the land use land cover is changing at an increasing rate within the study area as population also increases. Therefore, if the current trend continues without any measures been put in place to reduce the situation, then there could be an imbalance in the ecosystem

Urban warming as a result of the recent change in land use observed over Kumasi, has resulted in the alteration of the heat balance within the metropolis through anthropogenic activities, such as destruction of vegetative cover to create impervious layers of the built environment, combustion of fuel from domestic heating purposes, factories and traffic. This has reduced the potential for evapotranspiration, and contributed to the conversion of energy into sensible heat than latent heat [47]. The study also showed a gradual but significant increase in air temperatures for Kumasi within the period of the study $(1960-2015)$, causing rippling effects on other micro- climatic variables, posing much threat to the health of the inhabitants. It's worth noting that these trends are expected to rise, considering the recent global warming trend and an annual mean growth rate of $4.87 \%$ for most urban cities in Africa [59]. The enhanced effect of urbanization will have more negative impact on the both the weather and climate of these cities and the urban ecosystem, if the proper climate change mitigation and adaptive policies are not put in place by city planners [38]. Analysis of the long term climatic data for Kumasi from 1960 - 2015, considered for this study, showed a general increasing trend. The rate of increase of the daily minimum temperature at Kumasi $\left(1.55^{\circ} \mathrm{C} / 55\right.$ years $)$ was slightly lesser than the rate of change for the daily maximum temperature $\left(1.78^{\circ} \mathrm{C} / 55\right.$ years $)$ over the 55-year period. This shows a decrease in the daily mean temperature range 
Consequently, further increase in air temperatures, especially for nighttime, will be unbearable. Usually, tall buildings and impervious materials associated with the built-up environment heats the air trapped between them and prevent the outgoing thermal radiation from escaping these urban areas. This also affects the air quality and flow within these urban areas characterized with urban heat islands. The production of ozone at the surface level due to higher concentrations of volatile organic compounds, carbon monoxide, nitrogen oxides and other particulate matter from anthropogenic activities will be enhanced. Urban residents may resolve to cooling systems which will increase the energy demand of the city. Intense heat will also increase other respiratory diseases through bad air quality especially for places with poor ventilation systems. Outbreaks of respiratory and other diseases is more likely in the highly populated areas of Kumasi. Recent outbreak of the acute respiratory illness (H1N1) in the Kumasi metropolis, which was confirmed by the Ghana Health Service in the Kumasi, through a report by Ghana News Agency on 7th December 2017, showed that 4 death cases were recorded as against 44 reported cases. This is a clear sign of such effects due to urbanization. Also, the observed rise in temperature will affect the human body's ability to thermos-regulate and theoretically increase the risk of mortality through heat stress. Thermal stress will not only cause discomfort but indirectly lead to reduced mental and physical performance that will affect physiological and behavioural changes

Moreover, variability in rainfall as explained earlier will lead to years characterized with either drought or flood conditions. Thus, poor city drainage system and poor waste management system as observed in Kumasi, will lead to choking of gutters, which can further block the passage to lead to frequent flood events in the city. These flood events can lead to destruction to properties and life. Also, water quality is also expected to be affected, as during stormy or rainy conditions, hot pavements and rooftops transfer excess heat to rain water. This could drain into sewers and raise the water temperature in streams, rivers, lakes and ponds, further causing harm to aquatic life. This thermal pollution will increase water temperature and create thermal stress and shock for these aquatic species

As such, with the proper mitigation and adaptive policies put in place by the city planners, the effect of urban heat islands will be minimized. The adoption to white or reflective materials to build houses, roofs, pavements and roads to increase the overall albedo effect of the city is advisable. The application of such cool roofs (made from reflective materials), reflective glass, green roofs and light colored concrete will aid in reflecting up to 50\% more light and reduce ambient temperature. Green roofs will be excellent insulators during warmer months and cool the surrounding environment. The planting of deciduous trees and creation of green parks around the city will decrease the urban heat island effect. Air quality will also be enhanced as these plants absorb more of the atmospheric carbon dioxide $\left(\mathrm{CO}_{2}\right)$. Siting of buildings should be planned in ways to also allow the free movement of air flow within the city, to improve ventilation and air quality. Adherence to other climate change mitigation and adaptive policies like the application of renewable energy sources such as solar or biofuel technologies to meet the energy demand of urban cities like Kumasi, will limit the combustion of fossil fuels and reduce its harmful effects on the environment

Finally, regulations or legal frameworks needed to protect the remaining green parks and trees around the city should be set- up and rightly enforced to prevent further destruction to these green spaces. Inhabitants need to be educated on the importance of these green spaces in helping regulate the temperature within the city. This work is a contribution to environmental sustainability especially in modern cities like Kumasi. Further studies using other key technologies to better explain the effect of urbanization on the city's landscape is highly recommended, as Kumasi city planners need to be aware of the threat being posed, and encourage the use of environmentally friendly materials in construction, whiles still ensuring more green spaces especially at commercial areas

\section{Funding: This research received no external funding}

Conflicts of Interest: The authors declare no conflict of interest.

\section{Abbreviations}

The following abbreviations are used in this manuscript: 
MDPI Multidisciplinary Digital Publishing Institute

DOAJ Directory of open access journals

TLA Three letter acronym

LD linear dichroism

\section{References}

1. Abdolrahimi, M. The effect of El Niño Southern Oscillation (ENSO) on world cereal production. Master's Thesis, University of Sydney, 2016.

2. Adarkwa, K.K and Owusu-Akyaw. Development control in Kumasi. The fate of the tree, Planning and managing the development of Kumasi, Woeli Publishing Services, Accra, 2001, 199-208.

3. Arhin, K. and Afari-Gyan, K. The City of Kumasi: Past, present and future. Institute of African Studies, 1992.

4. Asare, G. E. Kumasi: the garden city without gardens. 2014.

5. Millenium Ecosystem Assessment. Ecosystem and human well-being: biodiversity synthesis. World Resources Institute, Washington, DC, 2005.

6. J. Atayi and A.K. Kabo-bah and K. Akpoti. THE EFFECTS OF LARGE-SCALE MINING ON LAND USE AND LAND COVER CHANGES USING REMOTELY SENSED DATA 1. International Journal of Science and nature 2016, 7,4, 724-733, 10.1016/S0031-8914(53)80099-6.

7. Bon, M. Melourne: Garden City - urban sprawl issues, Part4, 2014.

8. Author1, T. Energy and radiation balance of a central European city. International journal of Climatology 2004, 24, 11, 1395-1421, 10.1016/S0031-8914(53)80099-6.

9. J.F. Clarke. Some effects of the urban structure on heat mortality. Environmental Research 1972, 5, 1, 93-104.

10. B. Clark. Ebenezer Howard and the marriage of town and country: An introduction to Howard's garden cities of To-morrow. Organization and environment 2003, 16, 87-97.

11. P.B. Cobbinah and C. Amoako. Urban sprawl and loss of peri-urban land in Kumasi, Ghana. International Journal of Social and Human Sciences 2012, 6, 388-397.

12. D. Corovic. The Garden city concept: From theory to implementation. SAJ 2009, 1, 65-80.

13. P. Curtin. Medical knowledge and urban planning in colonial tropical Africa. The social basis of health and healing in Africa 1992, 235-255.

14. V.H. Dale and R.V. O'Neill and M. Pedlowski and F. Southworth. Causes and effects of land-use change in central Rondônia, Brazil. Photogrammetric engineering and remote sensing 1993, 6, 1395-1421.

15. M. Demuzere and K. Orru and O. Heidrich and E. Olazabal and D. Geneletti and H. Orru and M. Faehnle. Mitigating and adapting to climate change: Multi-functional and multi-scale assessment of green urban infrastructure. Journal of Environmental Management 2014, 146, 107-115.

16. R. Dinye and J. Edusei and R.S. King. District resources development handbook: Kumasi District. Department of Housing and Planning Research 1987.

17. M.K. Eduful. Impacts of Urban land use change on sources of drinking water in Kumasi, Ghana. University of Montana 2014.

18. R. Emmanuel and A. Loconsole. Green infrastructure as an adaptation approach to tackling urban overheating in the Glasgow Clyde Valley Region, UK. Landscape and Urban Planning 2015, 138, 71-86.

19. E. Erell and D. Pearlmutter and T. Williamson. Urban microclimate: Designing the spaces between buildings. Earthscan, London, UK 2011.

20. T. Gál and J. Unger. Detection of ventilation paths using high-resolution roughness parameter mapping in a large urban area. Building and Environment 2009, (44)1, 198-206.

21. C.S.B. Grimmond and T.R. Oke. Turbulent heat fluxes in urban areas: Observations and local- scale urban meteorological parameterization scheme (LUMPS). Journal of Applied Meteorology 2002, (41)7, 792-810.

22. Ghana Statistical Service. 2010 Population and Housing Census. Ghana Statistical Service 2010.

23. S. Hajat and S.C. Sheridan and O. M.J. Allen and M. Pascal and K. Laaidi and A. Yagouti and T. Kosatsky. Heat-health warning systems: a comparison of the predictive capacity of different approaches to identifying dangerously hot days. American journal of public health 2010, 100(6), 1137-1144.

24. P. Hall and M. Tewdwr- Jones. In Urban and regional planning.; Publishing House: Routledge, Taylor and Francis Group Ltd, UK, 2010; ISBN: 9781135173975. 
25. N. Horning. Electing the appropriate band combination for an RGB image using Landsat imagery. Center for Biodiversity and Conservation 2004.

26. E. Howard. In Garden cities of tomorrow; Lemur Books, 2014.

27. J.R. Jensen. Introductory digital image processing 3rd edition. Upper saddle river: Prentice hall 2005.

28. C.Y. Jim and M.W. Chan. Urban greenspace delivery in Hong Kong: spatial-institutional limitations and solutions. Urban Forestry E Urban Greening 2016, 18.

29. P.D. Jones and D.H. Lister and L.I. Qingxiang. Urbanization effects in large- scale temperature records, with an emphasis on China. Journal of Geophysical Research: Atmospheres 2008, 113.

30. J.J. Kashaigili and A.M. Majaliwa. Integrated assessment of land use and cover changes in the Malagarasi river catchment in Tanzania. Physics and Chemistry of the Earth 2010, (35)13-14, 730-741.

31. T. Karlessi and M. Santamouris and A. Synnefa and D. Assimakopoulos and P. Didaskalopoulos and K. Apostolakis. Development and testing of PCM doped cool colored coatings to mitigate urban heat island and cool buildings. Building and Environment 2011, (46)3, 570-576.

32. A. Koranteng. The study of the land use/cover of Kumasi and its environs using Landsat images. 2007.

33. E.F. Lambin and A. Strahler. Remotely-sensed indicators of land-cover change for multitemporal change-vector analysis. International Journal of remote sensing 1994, (15)10, 2099-2119, DOI.

34. E.H. Landsberg. The Urban climate. Academic Press 1981, 28.

35. L. Larsen. Urban climate and adaptation strategies. Frontiers in Ecology and the Environment 2015, 13(9), 486-492.

36. J. Li and C. Song and L. Cao and F. Zhu and X. Meng and J. Wu. Impacts of landscape structure on surface urban heat islands: a case study of Shanghai, China. Remote Sensing of Environment 2011, 115(12), 3249-3263.

37. D. Lu and S. Hetrick and E. Moran. Land cover classification in a complex urban-rural landscape with Quickbird imagery. Photogrammetric Engineering \& Remote Sensing 2010, 76, 1159-1168.

38. A. Manu and A.Y. Twumasi and L.T. Coleman. Is it the result of global warming or urbanization? The rise in air temperature in two cities in Ghana. Promoting Land Administration and Good Governance 5th FIG Regional Conference. Accra, Ghana 2006.

39. M. Maoulidi. A water and sanitation needs assessment for Kumasi, Ghana. Millennium Cities Initiative 2010.

40. T.C. McCaskie. Denkyira in the making of Asante c. 1660 - 1720. The Journal of African History 2007, 48(1), $1-25$.

41. C.A. Mensah. Is Kumasi still a garden city, Land use analysis between 1980 - 2010. Journal of Environment and Ecology 2014, (5)2, 89-107.

42. T. Matthews and A.Y. Lo and J.A. Bryne. Reconceptualizing green infrastructure for climate change adaptation: Barriers to adoption and drivers for uptake by spatial planners. Landscape and Urban Planning 2015, 138, 155-163.

43. C. Mensah and L.K. Amekudzi and N.A.B. Klutse and J.N.A Aryee and K. Asare. Comparison of Rainy Season Onset, Cessation and Duration for Ghana from RegCM4 and GMet Datasets. Atmospheric and Climate Sciences 2016, 6(2), 300-309, 10.4236/acs.2016.62025.

44. P. Moonen and T. Defraeye and V. Dorer and B. Blocken and J. Carmeliet. Urban Physics: Effect of the micro-climate on comfort, health and energy demand. Frontiers of Architectural Research 2012, (1)3, 197-228.

45. B.F. Nero and B.B. Campion and N. Agbo and D. Callo-Concha and M. Denich. Tree and trait diversity, species coexistence, and Diversity- functional relations of green spaces in Kumasi, Ghana. Procedia engineering 2017, 198, 99-115.

46. T.R. Oke. The energetic basis of the urban heat island. Quarterly Journal of the Royal Meteorological Society 1982, (108)455, 1-24.

47. T.R. Oke and G.T. Johnson and D.G Steyn and I.D. Watson. Simulation of surface urban heat islands under ideal conditions at night Part 2: Diagnoses of causation. Boundary layer Meteorology 1991, (56)4, 339-358.

48. T.W. Owen and T.N. Carlson and R.R. Gillies. An assessment of satellite remotely-sensed land cover parameters in quantitatively describing the climatic effect of urbanization. International journal of remote sensing 1998, (19)9, 1663-1681.

49. D.E. Parker. Urban heat island effects on estimates of observed climate change. Wiley Interdisciplinary Reviews: Climate Change 2010, (1)1, 123-133.

50. M. Poku-Boansi and D.K.B. Inkoom. Urbanization and human security in the Kumasi Metropolis. Future of the tree: Towards growth and development of Kumasi 2011, 234-248. 
51. V.K. Quagraine. Urban landscape depletion in the Kumasi Metropolis. Future of the tree: Towards growth and development of Kumasi 2011, 212-233.

52. S. Schmidt. Cultural influences and the built environment. An examination of Kumasi, Ghana. Journal of Urban Design 2005, (10)5, 353-370.

53. R.B. Stull. An introduction to boundary layer meteorology. Springer Science and Business Media 2012, 13.

54. A.A Tontoh. A study to ascertain the growth situation of the Kumasi Metropolitan Area (KMA): a remote sensing approach. Kwame Nkrumah University of Science and Technology 2011.

55. B. Tso and P.M Mather. In Classification methods for remotely sensed data; CRC Press, LC-0431, 2007.

56. U.N. Desa. World Urbanization prospects, the 2011 revision. Population Division, department of economic and Social affairs, United Nations Secretariat 2014.

57. Y. Wang and Q. Zhan and W. Ouyang. Impact of Urban Climate Landscape Patterns on Land Surface Temperature in Wuhan, China. Sustainability 2017, (9)10, 1700-1710.

58. Q. Weng. Modeling urban growth effects on surface runoff with the integration of remote sensing and GIS. Environmental management 2001, (28)6, 737-748.

59. M. Gillis and C. Shoup and G.P. Sicat. In World development report 2000/2001 attacking poverty; The World Bank, 2001.

60. C. Yuan and E. Ng. Building porosity for better urban ventilation in high-density cities-A computational parametric study. Building and Environment 2012, 50, 176-189. 